\title{
APLIKASI SISTEM KEUANGAN SYARIAH PADA PASAR UANG
}

Oleh :

\author{
Evan Hamzah Muchtar ${ }^{1} \&$ Siti Najma ${ }^{2}$ \\ Evan.hamzah.m@gmail.com \\ najmatajang@gmail.com
}

\begin{abstract}
Abstrak
Pasar uang merupakan tempat pertemuan antara pihak yang memiliki surplus dana dengan pihak yang mengalami defisit dana, dimana dananya berjangka pendek, yaitu dana berjangka waktu kurang dari satu tahun. Pasar uang dalam perspektif Islam hanya diperbolehkan pada pasar uang yang tidak menggunakan sistem bunga dan bisa diganti dengan alternatif akad seperti mudharabah, musyarakah, al-qard, wadiah, dan alsharf dan menghilangkan unsur gharar dan maysir yang terkandung didalamnya. Aplikasi sistem keuangan syariah pada pasar uang diantaranya adalah Sertifikat Bank Indonesia

Syariah (SBIS), Repurchase Agreement (Repo) SBIS, Surat Berharga Syariah Negara (SBSN), Repurchase Agrement (Repo) SBSN, dan Pasar Uang Antar Bank Syariah (PUAS).

Abstraction

The money market is a meeting place between parties who have a surplus of funds and those who experience a fund deficit, where funds are short-term, ie funds with maturities of less than one year. The money market in the Islamic perspective is only allowed on the money market that does not use the interest system and can be replaced with alternative contracts such as mudharabah, musyarakah, al-qard, wadiah, and al-sharf and removes the elements of gharar and maysir contained therein. The applications of the Islamic financial system on the money market include Bank Indonesia Syariah Certificates

(SBIS), Repurchase Agreement (Repo) SBIS, State Sharia Securities (SBSN), SBSN Repurchase Agrement (Repo), and Sharia Interbank Money Market (PUAS)
\end{abstract}

\section{Pendahuluan}

Pasar uang dibutuhkan dalam sistem perekonomian dikarenakan banyaknya perusahaan serta individu yang mengalami arus kas yang tidak sesuai antara dana masuk (inflows) dan dana keluar (outflows). Misalnya, perusahaan melakukan penagihan dari

\footnotetext{
${ }^{1}$ Dosen Tetap Program Studi Perbankan Syariah STAI Asy-Syukriyyah Tangerang

${ }^{2}$ Dosen Tetap Program Studi Ekonomi Syariah IAIN Lhokseumawe
} 


\section{Jurnal Asy-Syukriyyah}

klien pada periode tertentu dan pada waktu yang lain ia harus mengeluarkan uang untuk menutupi biaya operasionalnya. Satu cara yang dapat dilakukan untuk mengatasi masalah tersebut, pada saat kas perusahaan mengalami defisit, maka perusahaan dapat mencari sumber pembiayaan melalui pasar uang sebagai salah satu sarana alternatif untuk mencari modal kerja dengan melakukan peminjaman terhadap lembaga keuangan. Selanjutnya, pada saat perusahaan tersebut juga telah mengalami surplus dana, maka perusahaan tersebut juga dapat menjadi kreditor dalam pasar uang.

Pasar uang syariah juga mempunyai fungsi yang sama dengan pasar uang kovensional, namun dalam operasionalnya pasar finansial syariah tersebut dijalankan berdasarkan syariah. Peningkatan jumlah instrumen pasar uang di pasar uang syariah meningkatkan eksposur bank syariah untuk berbagai risiko seperti likuiditas, dan risiko kredit. Pasar uang syariah adalah bagian integral dari fungsi sistem perbankan syariah, pertama, dalam memberikan lembaga keuangan syariah dengan fasilitas pendanaan dan menyesuaikan portofolio dalam jangka pendek.

Ada beberapa prinsip dasar yang tidak bisa ditinggalkan dalam kita merancang bangun pasar uang syariah, seperti transaksi tidak pada objek yang diharamkan, tidak mengandung unsur riba, gharar dan maysir. Pasar uang dalam perspektif Islam hanya diperbolehkan pada pasar uang yang tidak menggunakan sistem bunga dan bisa diganti dengan alternatif akad seperti mudharabah, musyarakah, al-qard, wadiah, dan al-sharf dan menghilangkan unsur gharar dan maysir yang terkandung didalamnya.

\section{Aplikasi Sistem Keuangan Syariah pada Pasar Uang}

\section{Pengertian Pasar Uang}

Pasar uang merupakan tempat pertemuan antara pihak yang memiliki surplus dana dengan pihak yang mengalami defisit dana, dimana dananya berjangka pendek, yaitu dana berjangka waktu kurang dari satu tahun. Pasar uang melayani banyak pihak seperti pemerintah, bank, perusahaan asuransi, dan lembaga keuangan lainnya. Pihak yang mendapat manfaat dari pasar uang ini adalah pihak yang kekurangan dana, sedangkan bagi 


\section{Jurnal Asy-Syukriyyah}

pihak yang berkelebihan dana mendapat manfaat berupa peluang untuk menambah pendapatan dan sekaligus dapat mengurangi risiko finansial. ${ }^{3}$

Pasar uang berbeda dengan pasar modal yang perdagangannya dilakukan melalui Bursa atau Stock Exchange. Pasar uang sifatnya abstrak, tidak ada tempat khusus seperti halnya dengan pasar modal, transaksi pada pasar uang dilakukan secara OTC (Over The Counter Market), dilakukan oleh setiap peserta (partisipan) melalui desk atau dealing room masing-masing peserta.

Pasar uang pada saat ini tidak lagi dibatasi dalam wilayah suatu negara saja. Uang berputar ke seluruh bagian dunia, mencari investasi yang menawarkan expected return yang paling tinggi untuk suatu tingkat resiko tertentu sejalan dengan pesatnya perkembangan perdagangan dunia. Pertumbuhan dan perkembangan perdagangan internasional membutuhkan pembiayaan jangka pendek maupun jangka panjang. ${ }^{4}$

\begin{tabular}{|c|c|c|}
\hline \multicolumn{2}{|c|}{ Tabel 1. Perbedaan Pasar Uang dan Pasar Modal } \\
\hline Perihal & Pasar Uang & Pasar Modal \\
\hline Instrumen & $\begin{array}{c}\text { Jangka pendek } \\
(\leq 1 \text { tahun })\end{array}$ & Jangka panjang \\
\hline Bentuk pasar & Abstrak & Bursa efek \\
\hline Tujuan & $\begin{array}{r}\text { Investasi \& ekspansi } \\
\text { usaha }\end{array}$ & $\begin{array}{c}\text { Keuntungan \& penguasan } \\
\text { perusahaan }\end{array}$ \\
\hline
\end{tabular}

2. Instrumen Pasar Uang

a. Coupun bearing instrument/interest bearing; semua instrumen pasar uang dalam model ini dikaitkan dengan pembayaran suku bunga. Ada 3 jenis coupun bearing instrument yang digunakan dalam pasar uang :

${ }^{3}$ Abdul Manan, Aspek Hukum Dalam PenyelenggaraanInvestasi di Pasar Modal Syariah Indonesia, (Jakarta:Kencana 2009), h. 18.

$4 \quad$ Sudirman, Mizan, Volume 10 Nomor 1, Juni 2014

"Penentuan Pasar Uang dan Manfaatnya", dalam

Jurnal Al 


\section{Jurnal Asy-Syukriyyah}

- Money market deposits- non negotiable instrument

- Certicifate of deposits-negotiable instrument

- Repurchase agreement (Repo)- negotiable instrument

b. Money market deposits, pada money market deposits dikenal dua jenis instrumen yang tersedia pada pasar uang antar bank (inter bank markets), yaitu :

- Fixed deposit, yaitu tingkat suku bunga dan tanggal jatuh temponya telah disepakati pada waktu transaksi disetujui.

- Notice atau call deposit, yaitu tingkat suku bunga dan tanggal jatuh tempo dapat berubah-ubah dan bila diputuskan akan berakhir, maka dana tersebut berlaku efektif pada beberapa hari kemudian.

c. Certificate deposit adalah negotiable receipt for funds yang didepositokan pada suatu bank atau institusi keuangan lainnya dengan jangka waktu tertentu dan tingkat bunga tertentu yang diterima dimuka. Certificate deposit dapat diperjualbelikan karena merupakan instrumen yang negotiable dan tidak menyebutkan nama pemilik.

d. Repurchase Agreement (Repo), suatu perjanjian antara dua pihak, yang salah satu pihak setuju untuk menjual instrumen pasar uang tersebut dan sekaligus setuju untuk membeli kembali pada tanggal dan harga tertentu. Instrumen yang diperjualbelikan seperti ini biasanya instrumen yang digunakan bank sentral untuk kebijakan moneter.

e. Discount instrument, instrumen pasar uang dengan metode ini sama dengan bunga dibayar dimuka, yaitu selisih dari harga instrumen pada waktu membeli dikurangi dengan nilai pada saat jatuh tempo. Ada 3 instrumen negotiable discount instrument, yaitu :

- Treasury bill (T-Bill), merupakan instrumen utang yang diterbitkan oleh Pemerintah dan bank sentral atas tunjuk dengan jumlah tertentu yang akan dibayarkan kepada pemegang pada tanggal yang telah ditetapkan. 


\section{Jurnal Asy-Syukriyyah}

- Bill of exchange, adalah suatu perintah tertulis tak bersyarat yang ditujukan oleh seseorang kepada pihak lainnya untuk membayar sejumlah uang tertentu pada saat diperlihatkan atau pada tanggal tertentu kepada penarik atau pembawa.

- Bankers acceptance (BA), adalah perolehan letter of credit (L/C) dari bank untuk membeli barang dan jasa di mana pelanggan tidak diharuskan membayar kewajibannya pada waktu tertentu, tetapi bank penerbit LC yang melakukan pembayaran. BA dapat dijual dan dibeli sampai waktu jatuh tempo dengan tingkat bunga yang lebih rendah. ${ }^{5}$

- Commercial paper (CP), adalah promes yang tidak disertai dengan jaminan (unsecured promissory notes) yang diterbitkan oleh perusahaan untuk memperoleh dana jangka pendek dan dijual kepada investor yang melalukan investasi dalam instrumen pasar uang.

f. Derivatif, bisa diartikan sebagai instrumen keuangan yang nilainya tergantung dari turunan nilai aset yang menjadi dasarnya (underlying asset).

- Forward rate agreement (FRAs), kontrak di antara dua pihak ketika mereka sepakat atas tingkat suku bunga tertentu yang diterapkan untuk pinjaman atau deposit dengan kesapakatan. ${ }^{6}$

- Interest rate future (IRF), adalah transaksi perlindungan terhadap kemungkinan kenaikan atau penurunan tingkat bunga yang dapat mempengaruhi kegiatan usaha. Trader mencari kesempatan keuntungan yang terjadi sebagai akibat pergerakan sementara pasar. ${ }^{7}$

- Interest rate swap (IRS), adalah suatu transaksi derivatif antara dua pihak untuk melakukan swap pembayaran bunga atas pinjaman yang sama dengan tingkat suku

5 Jonni Manurung \& Adler Haymans Manurung, Ekonomi Keuangan dan Kebijakan Moneter, (Jakarta : Salemba Empat,2009), h. 64

${ }^{6}$ Bob Steiner, Foreign Exchange and Money Markets : Theory, Parctice, and Risk Management, (London : Butterworth-Heinemann, 2002), h. 63

${ }^{7}$ Dian Ediana Rae, Transaksi Derivatif dan Masalah Regulasi Ekonomi di Indonesia, (Jakarta : Elex Media komputindo, 2008), h. 59 


\section{Jurnal Asy-Syukriyyah}

bunga yang berbeda, biasanya yang satu bersifat tetap (fixed) dan yang lainnya mengambang (floating). ${ }^{8}$

Adapun instrumen pasar uang yang ada di Indonesia, yaitu :

\section{a. Sertifikat Bank Indonesia (SBI)}

SBI adalah suatu instrumen hutang yang diterbitkan atau yang berasal dari pemerintah atau bank sentral di negara tersebut atas dasar unjuk dengan jumlah yang tertentu dan akan dibayarkan kepada pemegang atau pemilik dana pada tanggal yang telah ditentukan dan disepakati bersama sebelumnya. Jangka waktu atau jatuh tempo instrumen ini kurang lebih satu tahun dengan sistem diskonto. SBI Indonesia merupakan salah satu mekanisme yang digunakan oleh Bank Indonesia dengan tujuan untuk mengontrol kestabilan nilai rupiah. SBI diterbitkan tanpa adanya warkat dan seluruh kepemilikan maupun transaksinya dicatat dan direkap dalam sarana Bank Indonesia. Pihak-pihak yang terlibat di sini adalah bank-bank umum dan masyarakat. ${ }^{9}$

\section{b. Surat Berharga Pasar Uang (SBPU)}

Surat berharga ini termasuk jenis surat yang memiliki jangka waktu pendek, dan gunanya untuk diperjualbelikan secara diskonto dengan Bank Indonesia atau lembagalembaga lain yang dalam naungan Bank Indonesia atau lembaga yang dirujuk atau ditunjuk oleh Bank indonesia.

${ }^{8}$ Veithzal Rivai dkk, Bank and Financial Institution Management Conventional \& Sharia System, (Jakarta : PT Raja Grafindo Persada, 2007), h. 849.

9 Sertifikat Bank Indonesia diterbitkan bukan tanpa tujuan, adanya sertifikat bank Indonesia diharapkan mampu memelihara kestabilan nilai rupiah yang ada. Dalam sebuah paradigma atau konsep yang dianut, jumlah uang primer (uang kartal dan uang giral yang beredar) yang berlebihan bisa mengurangi kestabilan nilai rupiah. Pada dasarnya sertifikat Bank Indonesia ini diterbitkan untuk mengurangi jumlah uang primer tersebut yang beredar di kehidupan masyarakat. Penerbitan sertifiikat ini dilandasi oleh suatu hukum yang melindunginya yakni Surat Keputusan Direksi Bank Indonesia no. 31/67/KEP/DIR tanggal 23 Juli 1998 yang berisi tentang penerbitan dan perdagangan sertifikat Bank Indonesia serta Intervensi rupiah. 


\section{Jurnal Asy-Syukriyyah}

\section{c. Sertifikat Deposito}

Sertifikat deposito merupakan salah satu instrumen keuangan yang diterbitkan oleh atas dasar unjuk dan dinyatakan dalam suatu jumlah, jangka waktu, tingkat bunga tertentu. Pada dasarnya sertifikat deposito ini merupakan deposito berjangka yang bukti simpanannya dapat diperdagangkan dan diperjualbelikan. Sertifikat deposito ini memiliki ciri pokok yang bisa membedakannya dengan deposito berjangka, yakni terletak pada sifatnya yang bisa dipindahtangankan atau diperjualbelikan sebelum jangka waktu atau tanggal jatuh temponya melalui lembaga-lembaga keuangan lainnya. ${ }^{10}$

\section{d. Commercial Paper}

Commercial paper ini merupakan promes yang tidak disertai dengan adanya jaminan yang diterbitkan oleh sebuah perusahaan dengan tujuan untuk memperoleh dana jangka pendek selanjutnya dijual kepada investor dalam pasar uang.

\section{e. Call Money}

Call money merupakan satu sistem dimana terjadi kegiatan pinjam meminjam dana antara satu bank dengan bank lainnya, dan digunakan untuk jangka waktu yang pendek. Pada dasarnya call money diartikan sebagai kredit atau pinjaman yang pelunasannya harus dengan segera apabila sudah mendapatkan panggilan atau peringatan dari pihak yang memberikan dana. Jangka waktu rata-rata waktu kredit adalah berkisar antara 1-7 hari.

\footnotetext{
${ }^{10}$ Adapun beberapa perbedaan antara sertifikat deposito dengan deposito berjangka, antara lain :
}

- Pemberian bunga pada sertifikat deposito akan dibayarkan dimuka tanpa ada syarat dan ketentuan khusus, berbeda dengan bunga deposito berjangka yang diberikan dan dibayarkan pada saar tanggal jatuh tempo.

- Kepemilikan dari sertifikat deposito bisa dialihkan kepada pihak lain karena penerbitan sertifikat ini atas unjuk bukan atas nama peroragan. Otomatis sertifikat deposito ini bisa diperjualbelikan kepada pihak lain.

- Jika sudah sampai tanggal jatuh tempo sertifikat deposito ini tidak bisa diperpanjang secara otomatis, tidak sama seperti deposito berjangka yang bisa dengan ototmatis diperpanjang.

- Sertifikat deposito ini atas unjuk bukan atas nama seseorang, maka si pemegang sertfikat harus hati-hati karena kalau sampai hilang dan ditemukan orang, maka orang yang menemukannya tadi bisa menggunakan sertifikat deposito ini, berbeda jika dengan deposito berjangka yang diterbitkan atas nama perorangan, kalau hilang bisa dilacak. 


\section{Jurnal Asy-Syukriyyah}

Pemberian call money ini fleksible bisa ditentukan sesuai dengan kesepakatan bersama, misalkan pelunasan yang dilakukan satu hari setelah kredit, maka hal ini dinamakan one day call money dan masih banyak lainnya.

\section{f. Repurchase Agreement (Repo)}

Repurchase agreement merupakan kegiatan yang bisa dibilang kegiatan yang timbal balik. Maksudnya adalah kegiatan ini merupakan sebua transaksi jual beli suratsurat berharga yang disertai dengan perjanjian. Perjanjian itu berisi bahwa si penjual akan membeli kembali surat-surat atu sertifikat berharganya yang telah dijual kepada pembeli pada waktu dan harga yang dusah ditentukan dan disepakati bersama terlebih dahulu

\section{g. Banker's Acceptence}

Instrumen jenis ini merupakan instrumen pasar uang yang khusus digunakan untuk memberikan kredit atau sebuah bantuan kepada importir dan eksportir untuk membantu mereka dalam upaya pembayaran dan pembelian sejumlah barang atau untuk membeli valuta asing.

\section{h. Treasury bills}

Merupakan salah satu instrumen dari pasar uang yang penerbitannya dilakukan oleh bank sentral yakni Bank Indonesia dengan jangka waktu kurang dari satu tahun atau tepat satu tahun, penerbitan instrumen ini juga ats dasar unjuk bukan perorangan serta dengan nominal tertentu. ${ }^{11}$

11 https://dosenekonomi.com/bisnis/investasi/instrumen-pasar-uang, diakses tanggal 12 Oktober 2017. 


\section{Jurnal Asy-Syukriyyah}

\section{Aplikasi Sistem Keuangan Syariah pada Pasar Uang}

Sebelum membicarakan tentang aplikasi keuangan syariah pada pasar uang, dipahami terlebih dahulu apa saja yang bisa menyebabkan terlarangnya sebuah transaksi dan implikasinya dalam pasar uang, yaitu :

a. Transaksi pada objek yang haram

Sebuah transaksi dilarang karena objek (barang dan/atau jasa) yang ditransaksikan juga dilarang, misalnya minuman keras, bangkai, daging babi, dan sebagainya. Dengan demikian transaksi jual beli minuman keras dan daging babi adalah haram, walaupun akad jual-belinya sah. Oleh karena itu, bila ada transaksi pasar uang yang merupakan representasi dari barang atau jasa yang dilarang maka transaksi tersebut termasuk dalam kategori dilarang.

b. Transaksi yang mengandung riba

Segala jenis transaksi riba, yakni menawarkan predetermined fixed-income (penentuan pendapatan yang berjumlah pasti di muka) sudah jelas tidak diperbolehkan secara Islam, terutama jika jumlah pendapatan tersebut ditentukan oleh besarnya pokok yang dimiliki, karena jelas masuk dalam kategori riba yang diharamkan.

c. Transaksi yang mengandung penipuan (gharar) dan judi (maysir). Suatu akad mengandung unsur gharar, karena tidak ada kepastian, baik mengenai ada atau tidak ada objek akad, besar kecil jumlah maupun penyerahan objek akad tersebut. Gharar sangat terkait erat dengan adanya unsur judi atau gambling. Perjudian didefinisikan sebagai permainan dengan salah satu pihak harus menanggung beban pihak lainnya sebagai akibat hasil permainan tersebut. ${ }^{12}$

Pasar uang dalam perspektif Islam hanya diperbolehkan pada pasar uang yang tidak menggunakan sistem bunga dan bisa diganti dengan alternatif akad seperti mudharabah, musyarakah, al-qard, wadiah, dan al-sharf dan menghilangkan unsur gharar dan maysir yang terkandung didalamnya.

12 Adiwarman A. Karim, Ekonomi Islam Suatu Kajian Kontemporer, (Jakarta: Gema Insani Press, 2001), h. 129 


\section{Jurnal Asy-Syukriyyah}

Pasar uang syariah merupakan mekanisme yang memungkinkan lembaga keuangan syariah untuk menggunakan instrumen pasar dengan mekanisme yang sesuai dengan prinsip-prinsip syariah baik untuk mengatasi persoalan kekurangan likuiditas maupun kelebihan likuiditas. ${ }^{13}$ Pasar uang syariah memungkinkan pelaku pasar untuk menjalankan fungsi sebagaimana pada pasar uang konvensional dengan pengecualian bahwa instrumen yang digunakan memenuhi ketentuan syariah Islam.

Di antara keputusan fatwa Dewan Syariah Nasional No.37/DSN-MUI/X/2002, tentang pasar uang antar bank berdasarkan prinsip syariah adalah sebagai berikut :

1. Pasar uang antarbank yang tidak dibenarkan menurut syariah yaitu pasar uang antar bank yang berdasarkan bunga.

2. Pasar uang antar bank yang dibenarkan menurut syariah yaitu pasar uang antar bank yang berdasarkan prinsip-prinsip syariah.

3. Pasar uang antar bank berdasarkan prinsip syariah adalah kegiatan transaksi keuangan jangka pendek antar peserta pasar berdasarkan prinsip-prinsip syariah.

4. Peserta pasar uang, adalah :

- Bank syariah sebagai pemilik atau penerima dana.

- Bank konvensional hanya sebagai pemilik dana

5. Akad yang dapat digunakan pada pasar uang antar bank berdasarkan prinsip syariah adalah : mudharabah, musyarakah, qard, wadhiah, al-sharf.

6. Pemindahan kepemilikan instrumen pasar uang menggunakan akad-akad syariah yang digunakan dan hanya boleh dipindahtangankan sekali. ${ }^{14}$

Tabel 2. menunjukkan bahwa pasar uang syariah menggunakan kontrak-kontrak syariah, khususnya untuk penerbitan dan perdagangan instrumen pasar uang syariah di mana pasar uang konvensional hanya menggunakan tipe kontrak berdasarkan hutang. Return investasi mudharabah antar bank dan juga investasi wakalah tidak ditentukan

\footnotetext{
${ }^{13}$ Andri Soemitra, Bank dan Lembaga Keuangan Syariah, (Jakarta : Kencana, 2015), h. 203.

${ }^{14}$ Veitzal Rivai, Islamic Financial Management, (Bogor : Ghalia Indonesia, 2010), h. 358.
} 


\section{Jurnal Asy-Syukriyyah}

sebelumnya bahkan hanya menentukan lamanya investasi. Di sisi lain, return dari komoditas murabahah ditetapkan dan investor diinformasikan penempatan dananya. Menariknya, pasar uang syariah tidak hanya diperuntukkan untuk lembaga keuangan syariah tetapi juga konvensional. ${ }^{15}$

Tabel 2. Perbedaan Antara Pasar Uang Syariah dan Konvensional

\section{Pasar Uang}

Pasar Uang Konvensional

\section{Syariah}

\begin{tabular}{|c|c|c|}
\hline Pasar Uang Antar Bank & $\begin{array}{l}\text { Menggunakan kontrak sesuai } \\
\text { syari'ah seperti mudharabah, } \\
\text { murabahah, dan wakalah }\end{array}$ & $\begin{array}{l}\text { Menerbitkan kontrak hutang } \\
\text { untuk penempatan dana }\end{array}$ \\
\hline $\begin{array}{ll}\text { Proses } & \text { Penerbitan } \\
\text { Instrumen } & \end{array}$ & $\begin{array}{l}\text { Harus sesuai syari'ah dan } \\
\text { disetujui Dewan Komite } \\
\text { Syari'ah }\end{array}$ & $\begin{array}{l}\text { Disetujui pembuat } \\
\text { kebijakan keuangan }\end{array}$ \\
\hline Struktur Instrumen & $\begin{array}{l}\text { Struktur berdasarkan aset, } \\
\text { modal, dan hutang }\end{array}$ & Struktur hutang \\
\hline Investor & $\begin{array}{l}\text { Investor Syariah dan } \\
\text { Konvensional }\end{array}$ & Investor Konvensional \\
\hline
\end{tabular}

Aplikasi sistem keuangan syariah syariah pada pasar uang terdapat dalam instrumen pasar uang syariah, diantaranya :

a. Sertifikat Bank Indonesia Syariah (SBIS)

Adalah surat berharga berdasarkan prinsip syariah berjangka waktu pendek dalam mata uang rupiah yang diterbitkan oleh Bank Indonesia. SBIS diterbitkan sebagai salah satu instrumen operasi pasar terbuka dalam rangka pengendalian moneter yang dilakukan

${ }^{15}$ Asyraf Wajdi Dusuki (Editor), Islamic Financial System : Principles \& Operations, Malaysia, International Shari'ah Reseearch Academy for Islamic Finance (ISRA), 2012, h. 360 


\section{Jurnal Asy-Syukriyyah}

berdasarkan Prinsip Syariah. Akad yang dapat digunakan untuk penerbitan instrumen SBIS adalah akad : mudharabah (muqharadah)/qiradh, musyarakah, ju'alah, wadiah, qardh, wakalah. SBIS yang saat ini sudah diterbitkan oleh Bank Indonesia menggunakan akad Ju'alah. ${ }^{16}$

SBIS $J u$ 'alah sebagai instrumen moneter boleh diterbitkan untuk pengendalian moneter dan pengelolaan likuiditas perbankan syari'ah. Dalam SBIS Ju'alah, Bank Indonesia bertindak sebagai jail (pemberi pekerjaan); bank syariah bertindak sebagai ma'jul lah (penerima pekerjaan); dan obyek/underlying ju'alah (mahall al-aqd) adalah partisipasi bank syariah untuk membantu tugas Bank Indonesia dalam pengendalian moneter melalui penyerapan likuiditas dari masyarakat dan menempatkannya di Bank Indonesia dalam jumlah dan jangka waktu tertentu.

Bank Indonesia dalam operasi moneternya melalui penerbitan SBIS mengumumkan target penyerapan likuiditas kepada bank-bank syariah sebagai upaya pengendalian moneter dan menjanjikan imbalan (reward/iwadh/ju'l) tertentu bagi yang turut berpartisipasi dalam pelaksanaannya. ${ }^{17} \mathrm{BI}$ menetapkan dan memberikan imbalan atas SBIS yang diterbitkan yang dibayarkan pada saat jatuh tempo, yakni sebesar SBI atas jasanya membantu pengendalian dan pemeliharaan keseimbangan moneter Indonesia. Pihak yang dapat memiliki SBIS adalah BUS dan UUS. ${ }^{18}$ Bank syariah boleh memiliki SBIS untuk memanfaatkan dananya yang belum dapat disalurkan ke sektor riil.

Mekanisme implementasi SBIS Ju'alah dapat dibagankan sebagai berikut: ${ }^{19}$

${ }^{16}$ Ahmad Ifham, Ini Lho Bank Syariah! Memahami Bank Syariah dengan Mudah, (Jakarta : Gramedia Pustaka Utama, 2015), h. 294. Ju'alah adalah janji atau komitmen (iltizam) untuk memberikan imbalan (reward/iwadh/ju'l) tertentu atas pencapaian hasil (natijah) yang ditentukan dari suatu pekerjaan. Pihak yang terlibat meliputi ja'il dan ma'jul lah. Ja'il adalah pihak yang berjanji akan memberikan imbalan tertentu atas pencapaian hasil pekerjaan (natijah) yang ditentukan. Ma'jul lah adalah pihak yang melaksanakan ju'alah. Lihat Fatwa DSN Nomor 64/DSN-MUI/XII/2007 tentang SBIS Ju'alah.

${ }^{17}$ Ibid, h.297.

Syariah

${ }^{18}$ Lihat Peraturan Bank Indonesia Nomor : 10/ 11 /PBI/2008 tentang Sertifikat Bank Indonesia

${ }^{19}$ Yadi Janwari, Lembaga Keuangan Syariah, (Bandung : Remaja Rosda Karya, 2015), h. 159. 


\section{Jurnal Asy-Syukriyyah}

\section{Gambar 1. Mekanisme Implementasi SBIS Ju'alah}

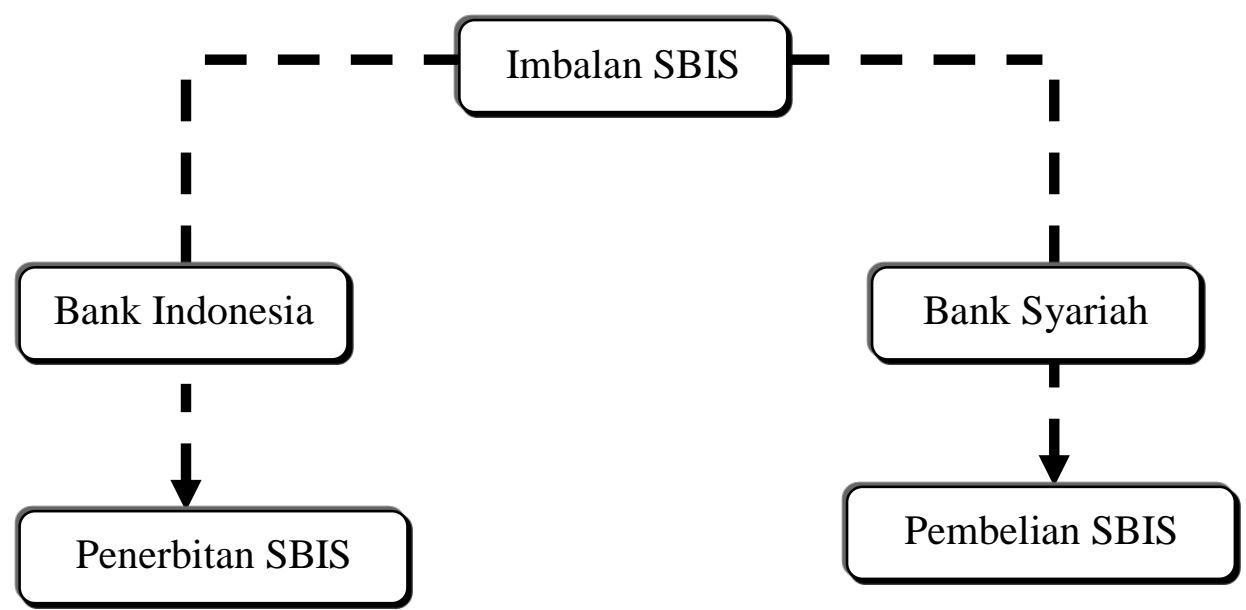

Lelang SBIS menyerap kelebihan likuiditas perekonomian melalui perbankan sifatnya non produktif karena dana yang diserap tidak untuk kegiatan riil perekonomian. Ketika jatuh tempo, pelunasan SBIS mengakibatkan penambahan likuiditas. Dana bank syariah yang ditempatkan di Bank Inddonesia melalui SBIS adalah wadiah amanah khusus yang ditempatkan dalam rekeninf SBIS Ju'alah, yaitu titipin dalam jangka waktu tertentu berdasarkan kesepakatan atau ketentuan BI, dan tidak dipergunakan oleh Bank Indonesia selaku penerima titipan,serta tidak boleh ditarik oleh bank syariah sebelum jatuh tempo. SBIS ju'alah ini merupakan instrumen moneter yang tidak dapat diperjualbelikan (non tradable) atau dipindahtangankan, dan bukan merupakan bagian dari portofolio investasi bank syariah. $^{20}$

\section{b. Repurchase Agreement (Repo) SBIS}

Adalah transaksi pemberian pinjaman oleh Bank Indonesia kepada BUS atau UUS dengan agunan SBIS (collateralized borrowing), di mana dalam repo tersebut kepemilikan efek akan tetap berada pada pihak penjual. Efek tersebut tidak dapat ditransfer atau dijual kembali sebelum tanggal transaksi Repo tersebut jatuh tempo.

\footnotetext{
${ }^{20}$ Ahmad Ifham, Ini Lho..,h. 299.
} 


\section{Jurnal Asy-Syukriyyah}

Karakteristik repo SBIS yaitu :

1) Bank syariah baik bank sendiri maupun unit usaha syariah dapat Me-repo-kan SBIS miliknya kepada Bank Indonesia dengan terlebih dahulu menandatangani perjanjian penggunaan SBIS dalam rangka REPO SBIS. Terhadap REPO SBIS, Bank Indonesia akan mengenakan biaya kepada BUS dan UUS.

2) Kedua, setelah itu BI mengumumkan biaya repo dan berjangka waktu satu hari kerja yang berlaku melalui BI-Scripless Securities Settlement System (BI-SSSS) dan atau sistem LHBU paling lambat sebelum window time REPO SBIS dibuka serta harus sesuai dengan waktu yang ditetapkan.

3) Ketiga, bank syariah yang sebelumnya telah menandatangi perjanjian pengagunan SBIS dalam rangka repo dan tidak dalam masa pengenaan sanksi, mengajukan repo SBIS Secara langsung melalui BI-SSSS selama window time dengan mencantumkan nilai nominal repo dan seri SBIS yang diagunkan (minimal memiliki sisa jangka waktu paling singkat dua hari kerja pada saat REPO SBIS jatuh tempo).

4) Keempat, dalam repo SBIS akad yang digunakan adalah akad qardh yang diikuti rahn. Repo SBIS).

Transaksi repo khusus syariah bisa memberikan manfaat kedua belah pihak baik bank syariah maupun Bank Indonesia. Hal ini dapat dilihat dari sisi pembeli (buyer) yakni Bank Indonesia karena berdasarkan peraturan Bank Indonesia di mana SBIS yang dimiliki bank syariah dapat di-repo-kan kepada Bank Indonesia. Dalam transaksi itu, Bank Indonesia akan memperoleh return untuk jangka waktu pendek (short term) dengan tingkat keuntungan menarik dan relatif aman karena pihak pembeli akan memegang jaminan berupa aset atau efek milik penjual. Efek tersebut juga bisa digunakan untuk menghindari terjadinya short positions. Sedangkan dari sisi penjual yakni bank syariah, dengan transaksi Repo Syariah dapat merupakan alternatif sumber pendanaan yang relatif murah (cheap funding cost) dan aman karena yang membeli adalah Bank Indonesia, dengan cara menyerahkan atau menjaminkan asetnya yang berupa efek tersebut. 


\section{Jurnal Asy-Syukriyyah}

Selain itu, dari sisi otoritas instrumen berdasarkan pada kebijakan, digunakan untuk pengendalian jumlah uang yang beredar sehingga perekonomian bisa tetap stabil. Namun bagi praktisi perbankan syariah, instrumen ini menjadikan alternatif solusi dalam mengatasi permasalahan likuiditas di bank syariah. Risiko yang muncul dari praktik merepo-kan SBIS adalah ketidakmampuan bank syariah untuk membeli kembali karena aset yang cenderung fix payment dalam jangka waktu menengah dan panjang. Dalam mekanismenya bank syariah harus memenuhi kewajiban membayar denda (gharamah) ${ }^{21}$ yang ditetapkan Bank Indonesia karena mereka tidak menepati jangka waktu kesepakatan pembelian SBIS.

\section{c. Surat Berharga Syariah Negara (SBSN)}

Definisi Surat Berharga Syariah Negara (SBSN) adalah surat berharga negara yang diterbitkan berdasarkan prinsip syariah, sebagai bukti atas bagian penyertaan terhadap aset SBSN, baik dalam mata uang rupiah maupun valuta asing. ${ }^{22}$ Aset SBSN adalah objek pembiayaan SBSN dan/atau barang milik negara yang memiliki nilai ekonomis, berupa tanah dan/atau bangunan maupun selain

tanah dan/atau bangunan, yang dalam rangka penerbitan SBSN dijadikan sebagai dasar penerbitan SBSN. Sehingga, maksud penerbitan SBSN adalah untuk membiayai APBN atau pembangunan proyek dan penerbitnya adalah pemerintah langsung atau perusahaan penerbit SBSN.

\section{Pemerintah Indonesia telah menerbitkan Project Based Sukuk (PBS) untuk}

${ }^{21}$ Berdasarkan PBI No. 10/11/PBI/2008 tentang SBIS salah satu poin adalah sanksi terhadap setiap transaksi SBIS yang dinyatakan batal dikenakan sanksi berupa : teguran tertulis; dan kewajiban membayar sebesar 1 permil (satu per seribu) dari nilai Transaksi SBIS yang dinyatakan batal atau paling banyak sebesar Rp1.000.000.000,00 (satu miliar rupiah). Sebagai contoh : jika nilai SBIS sebesar Rp 1.000.000.000, maka perhitungannya Rp1.000.000.000 x (1/1000) = Rp 1.000.000. Selain dikenakan sanksi tersebut di atas, BUS atau UUS juga dikenakan sanksi : pemberhentian sementara mengikuti lelang SBIS minggu berikutnya; dan larangan mengajukan repo SBIS selama lima hari kerja berturut-turut, terhitung sejak BUS atau UUS dikenakan teguran tertulis ketiga dalam kurun waktu enam bulan.

${ }^{22}$ Pasal 1 angka 1 UU No. 19 tahun 2008. Sedangkan dalam Fatwa Majelis Ulama Indonesia (MUI) No. 69/DSNMUI/VI/2008 tentang SBSN pada ketentuan umum angka 1 dinyatakan: Surat Berharga Syariah Negara atau dapat disebut Sukuk Negara adalah surat berharga negara yang diterbitkan berdasarkan prinsip syariah, sebagai bukti atas bagian (حصة (kepemilikan aset SBSN, baik dalam mata uang rupiah maupun valuta asing. 


\section{Jurnal Asy-Syukriyyah}

mendiversifikasikan instrumen Sukuk, lebih mengoptimalkan potensi underlying project yang tersedia dan mendukung proyek-proyek pembangunan nasional. Akad yang digunakan adalah ijarah asset to be leased (penyewaan aset yang ditelah dibangun) yaitu untuk pelaksanaan proyek-proyek seperti infrastruktur di APBN. Secara umum, persyaratan proyek yang akan didanai dengan PBS antara lain: (i) telah dialokasikan di APBN, (ii) termasuk di dalam anggaran pemerintah pusat, (iii) persiapan konstruksi project harus $100 \%$ selesai sebelum Sukuk diterbitkan, (iv) disetujui parlemen (dewan perwakilan rakyat), (v) bagian dari pembangunan jangka menengah (vi) sesuai dengan syariah dan, (vii) mendukung percepatan pembangunan nasional. Beberapa proyek yang telah dibiayai dengan PBS antara lain Cirebon Troya double track, elektrifikasi track di pulau jawa dan, hotel jamaah haji. ${ }^{23}$

Beberapa bentuk akad yang dapat digunakan dalam penerbitan $\mathrm{SBSN}^{24}$, yaitu sebagai berikut:

- $\quad$ SBSN ijarah, yaitu yang diterbitkan berdasarkan akad ijarah. Di mana salah satu pihak dapat bertindak sendiri atau melalui wakilnya menjual atau menyewakan hak manfaat atas suatu aset kepada pihak lain berdasarkan harga dan periode yang disepakati tanpa diikuti dengan pemindahan kepemilikan aset itu sendiri.

23 Rifki Ismal, Sekuritisasi SBSN untuk Pengembangan Pasar Keuangan Syariah Indonesia, Kumpulan Hasil Riset Terbaik Forum Riset Ekonomi dan Keuangan Syariah IV, Universitas Brawijaya Malang, 3-4 November 2015. Paper ini mengkaji kemungkinan sekuritisasi SBSN menjadi instumen pasar keuangan syariah baru (disebut S-SBSN) yang akan : (i) mengembangkan pasar keuangan syariah, (ii) menjadi alternatif operasi moneter syariah, dan (iii) meningkatkan partisipasi publik dalam pembangunan nasional melalui SBSN.

${ }^{24}$ Dilihat dari serinya : (1) SBSN seri Islamic Fixed Rate (IFR), adalah seri SBSN yang diterbitkan Pemerintah di pasar perdana dalam negeri yang ditujukan bagi investor dengan nominal pembelian yang cukup besar. IFR bersifat tradable (dapat diperdagangkan) dengan tingkat imbal hasil tetap. (2) SBSN seri SukukRitel (SR), adalah seri SBSN yang diterbitkan pemerintah dengan carabookbuilding di pasar perdana dalam negeri yang ditujukan bagi investor individu atau orang perseeorangan. Bersifat tradable dengan imbal hasil tetap. (3) SBSN seri Sukuk Negara Indonesia (SNI), adalah seri SBSN yang diterbitkan Pemerintah dalam denominasi valuta asing (US Dollar), bersifat tradable dengan imbal hasil tetap. (4) SBSN seri Sukuk Dana Haji Indonesia (SDHI), adalah SBSN yang diterbitkan berdasarkan penempatan Dana Haji dan Dana Abadi Umat dalam SBSN oleh Departemen Agama, penerbitan SDHI menggunakan akad Ijarah al-Khadamat dan bersifat non-tradable 


\section{Jurnal Asy-Syukriyyah}

- $\quad$ SBSN mudharabah, adalah sukuk yang merepresentasikan suatu proyek atau kegiatan usaha yang dikelola berdasarkan akad mudharabah, dengan menunjuksalah satu partner atau pihak lain sebagai mudharib (pengelola usaha) dalam melakukan pengelolaan usaha tersebut.

- SBSN musyarakah, adalah sukuk yang diterbitkan dengan tujuan mmeproleh dana untuk menjalankan proyekbaru, mengembagkan proyek yang sudah berjalan, atau untuk membiayai kegiatan bisnis yang dilakukan berdasarkan akad musyarakah, sehingga pemegang sukuk menjadi pemilik proyek atau aset kegiatan usaha tersebut, sesuai dengan kontribusi dana yang diberikan.

- $\quad$ SBSN istishna, adalah sukuk yang diterbitkan dengan tujuan mendapatkan dana yang akan digunakan untuk memproduksi suatu barang, sehingga barang yang akan diproduksi tersebut menjadi milik pemegang sukuk.

- SBSN berdasarkan akad-akad lain sepanjang tidak bertentangan dengan prinsip syariah. $^{25}$

\section{d. Repurchase Agrement (Repo) SBSN}

Adalah transaksi penjualan SBSN oleh bank kepada Bank Indonesia dengan janji pembelian kembali sesuai dengan hargaa dan jangka waktu yang disepakati dalam rangka standing facilities syariah. Transaksi ini dilakukan dalam rangka melakukan operasi moneter yaitu kontraksi likuiditas perbankan.

Repo SBSN memiliki karakteristik sebagai berikut :

1) Menggunakan akad al bai' (jual beli) yang disertai dengan al wa'ad (janji) oleh Bank kepada Bank Indonesia dalam dokumen terpisah untuk membeli kembali SBSN dalam jangka waktu dan harga tertentu yang disepakati.

2) Berjangka waktu paling lama 14 (empat belas) hari kalender.

3) Terhadap penggunaan Repo SBSN dikenakan biaya repo SBSN dengan rate sebesar BI-Rate + marjin 50 (lima puluh) bps.

${ }^{25}$ Rukhul Amin, "Surat Berharga Syariah Negara (SBSN) dan Pengaturannya di Indonesia”, dalam Jurnal Perbankan Syariah, Vol. 1 No.2, November 2016. 


\section{Jurnal Asy-Syukriyyah}

SBSN yang direpokan harus memenuhi persyaratan :

4) Merupakan jenis dan seri yang ditetapkan oleh Bank Indonesia dapat direpokan.

5) Tercatat dalam Rekening Perdagangan di BI-SSSS.

6) Memiliki sisa jangka waktu paling singkat 10 (sepuluh) hari kerja yang dihitung 1 (satu) hari setelah Repo SBSN jatuh tempo. ${ }^{26}$

\section{e. Pasar Uang Antarbank Syariah (PUAS)}

Adalah kegiatan transaksi keuangan jangka waktu pendek antarbank berdasarkan prinsip syariah baik dalam rupiah maupun valuta asing. Pasar Uang Antarbank Berdasarkan Prinsip Syari'ah (PUAS) merupakan kegiatan transaksi keuangan jangka pendek antarbank berdasarkan prinsip syariah baik dalam rupiah maupun valuta asing. Peserta PUAS terdiri dari Bank Syariah, UUS, dan Bank Konvensional. Bank Syariah dan UUS dapat melakukan penempatan dan dan atau penerimaan dana dengan menggunakan instrumen PUAS yang ditetapkan oleh BI. ${ }^{27}$ Akad yang dapat digunakan dalam PUAS adalah mudharabah (muqharadah)/qiradh, musyarakah, wadiah qardh, wakalah.

Instrumen yang digunakan oleh pelaku pasar dalam transaksi PUAS adalah adalah Sertifikat Investasi Mudharabah Antarbank (SIMA) dan Sertifikat Perdagangan Komoditi Berdasarkan Prinsip Syariah Antarbank (SiKA). Dalam rangka mendorong pengembangan PUAS, BI telah melakukan penyempurnaan ketentuan, antara lain mencakup penyempurnaan peserta PUAS yaitu menambahkan Bank Asing, peran pialang pasar uang dalam transaksi PUAS, mekanisme pengalihan kepemilikan instrumen PUAS sebelum jatuh waktu dan pengenaan sanksi. ${ }^{28}$

\section{1) SIMA}

Sertifikat Investasi Mudharabah Antarbank berdasarkan prinsip syari'ah (SIMA) adalah instrumen dari kegiatan Pasar Uang Antarbank Berdasarkan Prinsip Syari'ah (PUAS). SIMA adalah sertifikat yang diterbitkan oleh Bank Umum Syari'ah atau Unit

${ }^{26}$ www.bi.go.id/id/peraturan/moneter/Documents/, diakses tanggal 17 Oktober 2017.

${ }^{27}$ Lihat Peraturan Bank Indonesia Nomor 17/4/PBI/2015 tanggal 27 April 2015 Tentang Pasar Uang Antarbank Berdasarkan Prinsip Syariah.

${ }^{28}$ Otoritas Jasa Keuangan, Booklet Perbankan Indonesia 2016, Edisi Maret 2016 


\section{Jurnal Asy-Syukriyyah}

Usaha Syari'ah (UUS) yang digunakan sebagai transaksi PUAS. ${ }^{29}$ SIMA ini digunakan sebagai sarana investasi bagi bank yang kelebihan dana untuk mendapatkan keuntungan dan di lain pihak untuk mendapatkan dana jangka pendek bagi bank syari'ah yang mengalami kekurangan dana, dengan menerbitkan SIMA $^{30}$ guna memperoleh dana dari bank lainnya, baik dari bank syari'ah maupun dari bank konvensional. Dalam pelaksanaannya sertifikat ini berdasarkan akad mudharabah.

\section{Gambar 2. Mekanisme Transaksi SIMA}

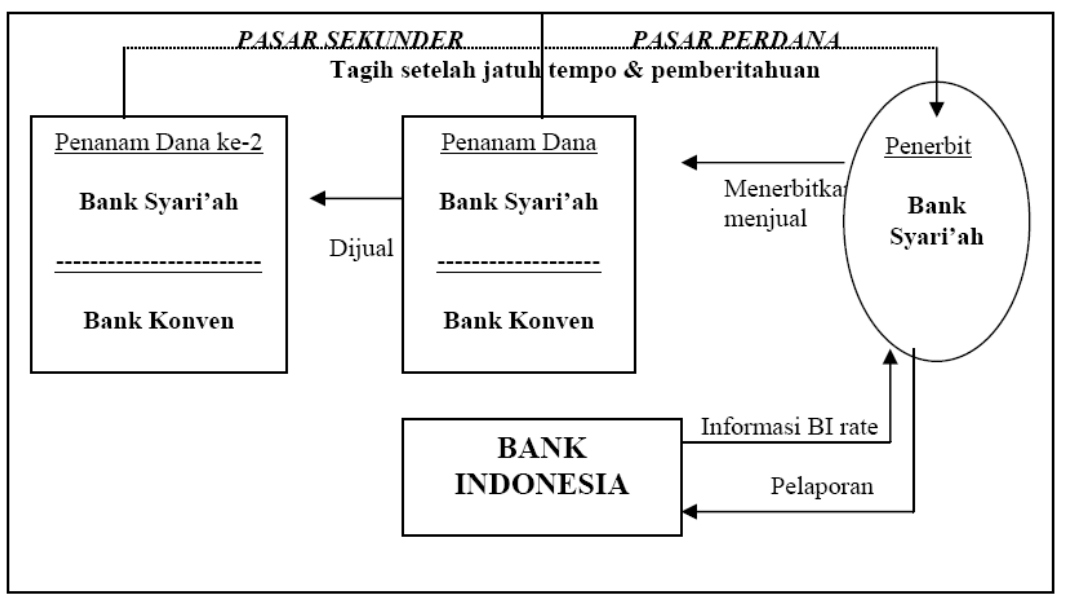

SIMA memiliki syarat pencantuman informasi jenis aset yang menjadi dasar penerbitan SIMA pada saat penerbitan SIMA. Ketentuan terkait SIMA tersebut memungkinkan bank untuk memilih aset mana yang akan digunakan sebagai underlying ketika akan menerbitkan SIMA, sehingga memudahkan bank untuk menentukan nisbah bagi hasil dari aset yang telah ditetapkan (bukan pooling pembiayaan).

${ }^{29}$ Surat Edaran Bank Indonesia No.9/8/DPM tentang SIMA

30 DSN-MUI juga telah mnegeluarkan fatwa untuk penerbitan SIMA ini dalam No.38/DSNMUI/X/2002, dengan ketentuan yang termuat adalah:

- Sertifikat Investasi Antarbank yang berdasarkan bunga tidak dibenarkan menurut syari'ah.

- Sertifikat investasi yang berdasarkan pada akad mudharabah dibenarkan menurut syari'ah.

- SIMA dapat dipindahtangankan hanya satu kali setelah dibeli pertama kali.

- Pelaku transaksi SIMA adalah Bank Umum Syari'ah sebagai pemilik atau penerima dana, dan bank konvensional hanya sebagai pemilik dana. 


\section{Jurnal Asy-Syukriyyah}

\section{2) $\mathrm{SiKA}$}

Sertifikat Perdagangan Komoditi Berdasarkan Prinsip Syariah Antarbank (SiKA) adalah sertifikat yang diterbitkan berdasarkan prinsip syariah oleh BUS atau UUS dalam transaksi PUAS yang merupakan bukti jual beli dengan pembayaran tangguh atas perdagangan komoditi di Bursa.

SiKA mempunyai karakteristik dan persyaratan sebagai berikut :

a) Diterbitkan atas dasar transaksi jual beli Komoditi di Bursa dengan menggunakan akad murabahah.

b) Diterbitkan dalam rupiah.

c) Dapat diterbitkan dengan atau tanpa warkat (scripless).

d) Berjangka waktu satu hari (over night) sampai 365 hari.

e) Tidak dapat dialihkan kepemilikannya sepanjang belum jatuh tempo. ${ }^{31}$

\section{Gambar 3. Mekanisme Transaksi SiKA}

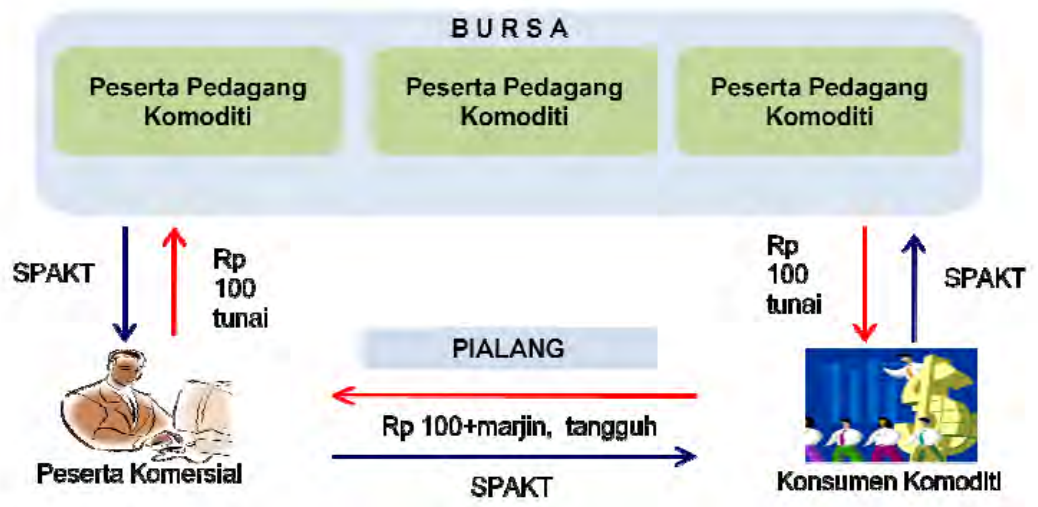

Ada beberapa akad yang digunakan dalam pelaksanaan SiKA ini, Pertama adalah bay', dimana peserta komersial akan membeli komoditi dari supplier lalu supplier memenuhi permintaan sesuai dengan komoditi yang dinginkan lalu dijual kepada peserta komersial dengan cara tunai. Kedua, murabahah dimana peserta komersial akan menjual

31 Surat Edaran Bank Indonesia No.14/3/DPM tanggal 4 Januari 2012 perihal Sertifikat Perdagangan Komoditi Berdasarkan Prinsip Syariah. Surat Edaran ini didukung oleh Fatwa DSN-MUI No.82/DSN-MUI/VIII/2011 tanggal 5 Agustus 2011 tentang Perdagangan Komoditi Berdasarkan Prinsip Syariah di Bursa Komoditi 


\section{Jurnal Asy-Syukriyyah}

asset ini atas kelebihan margin di atas pokok dengan cara tangguh atau cicilan. Ketiga, bay' musawamah dimana supplier diwakilkan oleh BBJ menjual barang ke peserta komersial tanpa berkewajiban memberitahukan berapa harga pokok dan margin. Keempat, wakalah, dimana BBJ akan menjual asset tersebut jika diperlukan oleh konsumen komoditi untuk menjualnya kepada supplier yang berbeda dari supplier awal. Kelima, akad mиqorodhoh, dimana supplier satu bisa barter asset dengan supplier 2, ataupun ke supplier 3 dan sebaliknya. Supaya asset tersebut tidak kembali kepada orang yang sama.

Dari lima akad ini, sebenarnya ada satu akad lagi yang harus diperhatikan, yaitu al$w a^{\prime} d u$. atas perjanjian dimana ketika konsumen komoditi menginginkan komoditas kepada peserta komersial dengan tujuan mendapatkan uang tunai maupun menahan asset tersebut untuk dijual dimasa yang akan datang atau dijual

ke selain peserta supplier dari Bursa komoditi syariah. konsumen komoditi harus berjanji membeli barang yang dibeli oleh peserta komersial. Jikalau tidak, maka ketika komoditas tersebut sudah dibeli oleh peserta komersial lalu konsumen komoditi membatalkan transaksi tersebut. Maka akan terjadi permasalahan disana,

bisa jadi asset yang dibeli oleh peserta komersial turun harga, pertanyaannya adalah, siapakah yang mau menanggung kerugian dari pembatalan transaksi ini? Oleh sebab itu, haruslah ada akad $a l$-wa'du disana sehingga konsumen komoditi berjanji akan membeli komoditi tersebut dari peserta komersial.

\section{Kesimpulan}

Pasar uang syariah merupakan mekanisme yang memungkinkan lembaga keuangan syariah untuk menggunakan instrumen pasar dengan mekanisme yang sesuai dengan prinsip-prinsip syariah baik untuk mengatasi persoalan kekurangan likuiditas maupun kelebihan likuiditas. Pasar uang syariah memungkinkan pelaku pasar untuk menjalankan fungsi sebagaimana pada pasar uang konvensional dengan pengecualian bahwa instrumen yang digunakan memenuhi ketentuan syariah Islam. 


\section{Jurnal Asy-Syukriyyah}

Aplikasi sistem keuangan syariah syariah pada pasar uang terdapat dalam instrumen pasar uang syariah, diantaranya :

a. Sertifikat Bank Indonesia Syariah (SBIS); adalah surat berharga berdasarkan prinsip syariah berjangka waktu pendek dalam mata uang rupiah yang diterbitkan oleh Bank Indonesia.

b. Repurchase Agreement (Repo) SBIS; dalah transaksi pemberian pinjaman oleh Bank Indonesia kepada BUS atau UUS dengan agunan SBIS (collateralized borrowing), di mana dalam repo tersebut kepemilikan efek akan tetap berada pada pihak penjual.

c. Surat Berharga Syariah Negara (SBSN); adalah surat berharga negara yang diterbitkan berdasarkan prinsip syariah, sebagai bukti atas bagian penyertaan terhadap aset SBSN, baik dalam mata uang rupiah maupun valuta asing.

d. Repurchase Agrement (Repo) SBSN; adalah transaksi penjualan SBSN oleh bank kepada Bank Indonesia dengan janji pembelian kembali sesuai dengan hargaa dan jangka waktu yang disepakati dalam rangka standing facilities syariah.

e. Pasar Uang Antarbank Syariah (PUAS); adalah kegiatan transaksi keuangan jangka waktu pendek antarbank berdasarkan prinsip syariah baik dalam rupiah maupun valuta asing. Instrumen yang digunakan oleh pelaku pasar dalam transaksi PUAS adalah adalah Sertifikat Investasi Mudharabah Antarbank (SIMA) dan Sertifikat Perdagangan Komoditi Berdasarkan Prinsip Syariah Antarbank (SiKA). SIMA adalah instrumen dari kegiatan Pasar Uang Antarbank Berdasarkan Prinsip Syari'ah (PUAS). SiKA adalah sertifikat yang diterbitkan berdasarkan prinsip syariah oleh BUS atau UUS dalam transaksi PUAS yang merupakan bukti jual beli dengan pembayaran tangguh atas perdagangan komoditi di Bursa. 


\section{Jurnal Asy-Syukriyyah}

\section{DAFTAR PUSTAKA}

Amin, Rukhul, "Surat Berharga Syariah Negara (SBSN) dan Pengaturannya di Indonesia”, dalam Jurnal Perbankan Syariah, Vol. 1 No.2, November 2016.

Dusuki, Asyraf Wajdi, (Editor), Islamic Financial System : Principles \& Operations, Malaysia, International Shari'ah Reseearch Academy for Islamic Finance (ISRA), 2012.

Fatwa DSN No.38/DSN-MUI/X/2002 Tentang Sertifikat Investasi Mudharabah Antar Bank (SIMA).

Fatwa DSN Nomor 64/DSN-MUI/XII/2007 tentang SBIS Ju'alah.

Fatwa DSN-MUI No.82/DSN-MUI/VIII/2011 tanggal 5 Agustus 2011 tentang Perdagangan Komoditi Berdasarkan Prinsip Syariah di Bursa Komoditi

Fatwa Majelis Ulama Indonesia (MUI) No. 69/DSNMUI/VI/2008 tentang SBSN.

Ifham, Ahmad, Ini Lho Bank Syariah! Memahami Bank Syariah dengan Mudah, (Jakarta : Gramedia Pustaka Utama, 2015).

Ismal, Rifki, Sekuritisasi SBSN untuk Pengembangan Pasar Keuangan Syariah Indonesia, Kumpulan Hasil Riset Terbaik Forum Riset Ekonomi dan Keuangan Syariah IV, Universitas Brawijaya Malang, 3-4 November 2015.

Janwari, Yadi, Lembaga Keuangan Syariah, (Bandung : Remaja Rosda Karya, 2015). 


\section{Jurnal Asy-Syukriyyah}

Karim, Adiwarman A, Ekonomi Islam Suatu Kajian Kontemporer, (Jakarta: Gema Insani Press, 2001).

Manan, Abdul, Aspek Hukum Dalam PenyelenggaraanInvestasi di Pasar Modal Syariah Indonesia, (Jakarta:Kencana 2009).

Manurung, Jonni \& Adler Haymans Manurung, Ekonomi Keuangan dan Kebijakan Moneter, (Jakarta : Salemba Empat,2009).

Otoritas Jasa Keuangan, Booklet Perbankan Indonesia 2016, Edisi Maret 2016

Peraturan Bank Indonesia Nomor 17/4/PBI/2015 tanggal 27 April 2015 Tentang Pasar Uang Antarbank Berdasarkan Prinsip Syariah.

Peraturan Bank Indonesia Nomor : 10/ 11 /PBI/2008 tentang Sertifikat Bank Indonesia Syariah.

Rae, Dian Ediana, Transaksi Derivatif dan Masalah Regulasi Ekonomi di Indonesia, (Jakarta : Elex Media komputindo, 2008).

Rivai, Veithzal, dkk, Bank and Financial Institution Management Conventional \& Sharia System, (Jakarta : PT Raja Grafindo Persada, 2007).

Rivai, Veitzal, Islamic Financial Management, (Bogor : Ghalia Indonesia, 2010).

Soemitra, Andri, Bank dan Lembaga Keuangan Syariah, (Jakarta : Kencana, 2015). 


\section{Jurnal Asy-Syukriyyah}

Steiner, Bob, Foreign Exchange and Money Markets : Theory, Parctice, and Risk Management, (London : Butterworth-Heinemann, 2002).

Sudirman, "Penentuan Pasar Uang dan Manfaatnya", dalam Jurnal AlMizan, Volume 10 Nomor 1, Juni 2014

Surat Edaran Bank Indonesia No.14/3/DPM tanggal 4 Januari 2012 perihal Sertifikat Perdagangan Komoditi Berdasarkan Prinsip Syariah.

Surat Edaran Bank Indonesia No.9/8/DPM tentang SIMA

Surat Keputusan Direksi Bank Indonesia no. 31/67/KEP/DIR tanggal 23 Juli 1998 tentang penerbitan dan perdagangan sertifikat Bank Indonesia serta Intervensi rupiah.

www.bi.go.id/id/peraturan/moneter/Documents/, diakses tanggal 17 Oktober 2017.

www.dosenekonomi.com/bisnis/investasi/instrumen-pasar-uang, diakses tanggal 12 Oktober 2017. 